\title{
イグサの機能性と食品産業への新展開
}

\author{
森田 洋 $^{1, \dagger}$, 塩澤正三 ${ }^{2}$, 志水由紀 ${ }^{3}$, 宮野麻紀子 ${ }^{4}$, 稲田剛夫 ${ }^{5}$ \\ ${ }^{1}$ 北九州市立大学国際環境工学部環境化学プロセス工学科, ${ }^{2}$ 国立八代工業高等専門学校生物工学科 \\ ${ }^{3}$ 王樹製薬株式会社, ${ }^{4}$ ワンドリーム有限会社, ${ }^{5}$ イナダ有限会社
}

\section{Physiological Functions of Igusa and the Application to Food Industry}

\author{
Hiroshi MORITA $^{1, \dagger}$, Masami SHIOZAWA ${ }^{2}$, Yuhki SHIMIZU ${ }^{3}$, Makiko MIYANO ${ }^{4}$ \\ and Takeo INADA ${ }^{5}$
}

\author{
${ }^{1}$ Department of Chemical Processes and Environments, Faculty of Environmental Engineering, \\ The University of Kitakyushu \\ ${ }^{2}$ Department of Bioengineering, Yatsushiro National College of Technology \\ ${ }^{3}$ Oujyu Pharmaceutical Co., Ltd. \\ ${ }^{4}$ One Dream Co., Ltd. \\ ${ }^{5}$ Inada Co., Ltd.
}

\begin{abstract}
The Igusa has strong scum and is not well suited for consumption, but by boiling it in water for 3 minutes the palatability could be enhanced. Dietary fiber contents of Igus $a$ are very high level $(63 \mathrm{~g} / 100$ $\mathrm{g}$-dry weight) in 14 kinds of agricultural products. The antibiotic showed a broad spectrum of activity (MIC; $0.78 \sim 100 \mu \mathrm{g} / \mathrm{ml})$. The bacterial population in a cake (Igusa-free), which have been preserved for 3 days at $30^{\circ} \mathrm{C}$, is about 2 orders more than that supplemented with Igusa at a concentration of $40 \mathrm{~g} / 100 \mathrm{~g}$-cake. The bacterial population in tofu preservative (Igusa-free), which has been kept for 4 days at $15^{\circ} \mathrm{C}$, is about 2 orders more than that supplemented with Igusa at a concentration of $0.1 \mathrm{~g} / \mathrm{ml}$. Consequently, it is thought that Igusa can be used as a keeping quality agent for the purpose of inhibiting bacterial proliferation. Igusa had a superoxide radical scavenging activity of $4200 \mathrm{units} / \mathrm{g}$. In the future, we consider that use of Igusa may be spread from health food industry to medical industry, and should advance in demand for the depressed Japanese Igusa industry by creating a new industry in addition to Tatami mat.
\end{abstract}

Key words: Juncus, antibiotic activity, keeping quality agent, superoxide radical scavenging activity, dietary fiber

\section{1.はじめに}

日本において睤の原材料として約 600 年前より用いら れてきたイグサはJuncus 属に分類される植物である. Juncus 属の植物は比較的湿度の高い地域で育ちやすく, 日本，中国，東南アジアを中心に世界においても約 220 種が分布している。日本に打けるイグサの栽培産地は熊 本県, 福岡県, 岡山県, 高知県などである。沖縄県に おいてもイグサのことを「ビーグ」と呼んでおり，敷物

(受付 2002 年 9 月 2 日。受理 2002 年 10 月 8 日

1 ₹ 808-0135 北九州市若松区ひびきの1-1

2 个 866-8501 八代市平山新町 2627

3 于 861-4101 熊本市近見 7 丁目 10-1

4 于 806-0073 北九州市八幡西区町上津役東 1-6-18

5 ₹ 869-4202 熊本県八代郡鏡町内田 $438-2$

†北九州市立大学国際環境工学部

Tel: 093-695-3289, Fax: 093-695-3381, E-mail: morita@env.kitakyu-u.ac.jp
の原材料として栽培している。目本におけるイグサの最 大産地は，熊本県八代地方であり，その年間生産量は 国内の $90 \%$ 以上を占めている. 現在, 日本の年間イグ サ生産量は約 29,000 トンであるが，この 10 年でイグサ の年間生産量は打よそ半分以下にまで減少している 1 , 2]. その主な要因は建物の洋風化と中国からの安い輸入 イグサの影響であり、イグサの新たな用途開発, 新産業 の創出が望まれている.

イグサは畳としての歴史もあるが，薬草としての歴史 も存在している[3]．和漢薬[4]によると，イグサは毒性 がなく, 利尿薬，消炎薬などの薬草としての効能がある と記されている。また切り傷, 出血, 打撲にイグサを噛 み潰したものを塗布すると症状が改善されると書かれて いる.さらに漢薬の臨床と応用[5]では, 利尿薬として, あるいは水腫の治療薬として，一回 $1.5 \sim 3 \mathrm{~g}$ 服用す るとよいと書かれている。このようなイグサの薬理効果, 
あるいは機能性に関する研究は現在ほとんど行われてい ない.

八代地方においては，約 8 年前よりイグサを添加した 食品（そうめん，まんじゅう，アイスクリームなど）が 市場に出始めている。これらは土産物として作り始めた そうであるが，イグサの機能性を次々と明らかにしてい くことで，今までは土産物でしかなかったイグサの食品 が，多くの食品産業へとその需要を日本全国に広げてゆ くことが可能ではないかと考えられる。本論文ではイグ サの機能性について解説を行い，それらの成果をもとに どのように食品産業へと応用できるかについて述べるこ ととする

\section{2. イグサの官能試験}

研究に使用したイグサ (Juncus effusus var. decipi$e n s)$ はすべて八代産（1998 年産）のものを用いた。イグ サの苗を 12 月に畑に植え付け，研究結果に影響が出な いように無農薬で一貫して栽培して，5月ごろにイグサ が $150 \mathrm{~cm}$ 程度の丈にまで伸長したものを刈り取った。

イグサには灰汁が多いことから，そのままでは食用に あまり適さない。そこでイグサを水で数分間煮ることに より，抹茶のような爽やかな風味へと変化することを明 らかにした。灰汁抜きの効果を証明するために，3 分間 水煮処理をしたイグサと生イグサをそれぞれ粉末化（増 幸産業株式会社製，型式 MK アトマイザーMKA-5Jに より，平均粒子径 $18.6 \mu \mathrm{m}$ にまで粉砕）したものを， 八代市在住の 20 代から 40 代の男女あわせて 30 名に， 香り，味，総合評価でどちらが好ましいかを判定しても らい，二点嗜好試験法 [6] により解析を行った。その 結果， $0.1 \% の$ 危険率でほとんどの被験者が香り，味， 総合評価で，水煮処理のイグサの方が好ましいと評価し た。つまりイグサは水煮処理を行うことで，嗜好性を高 められることが明らかとなった。

\section{3. イグサの食物繊維量}

イグサの一般的な化学組成を Table 1 に示す.イグ サは無水物換算でタンパク質が $18.9 \%$ ，脂肪が $0.6 \%$, 糖質 $11.0 \%$ ，食物繊維 $63.0 \%$ ，死分 $6.5 \%$ であり，力 ロリー (平成 8 年厚生省告示第 126 号によるエネルギー 換算）は $125 \mathrm{kcal} / 100 \mathrm{~g}$-無水物であった。イグサの成 分の中で特筆されることは，食物繊維含量が多いことで ある。イグサは食物繊維が無水物換算で $100 \mathrm{~g}$ あたり $63 \mathrm{~g}$ もの量を占めている。これは様々な農作物と比較し た場合に高い值である。Fig. 1 に代表的な農作物の食 物繊維含量を示す。モロへイヤ、ゴボウ，ケール，パセ リ，シシトウは無水物換算で $40 \%$ 程度，ピーマン，木 ウレンソウ，ニラは30 35\%程度，小麦胚芽，ゴマ，
Table 1 Chemical composition of Juncus effusus var. decipiens.

\begin{tabular}{lc}
\hline Component & (g/100 g-dry) \\
\hline protein & 18.9 \\
fat & 0.6 \\
dietary fiber & 63.0 \\
sugar & 11.0 \\
ash & 6.5 \\
& \\
potassium & 2.37 \\
calcium & 0.16 \\
magnesium & 0.11 \\
sodium & $34 \times 10^{-3}$ \\
iron & $3.3 \times 10^{-3}$ \\
& \\
ascorbic acid & $7.0 \times 10^{-3}$ \\
$\beta$-carotene & $6.5 \times 10^{-3}$ \\
\hline
\end{tabular}

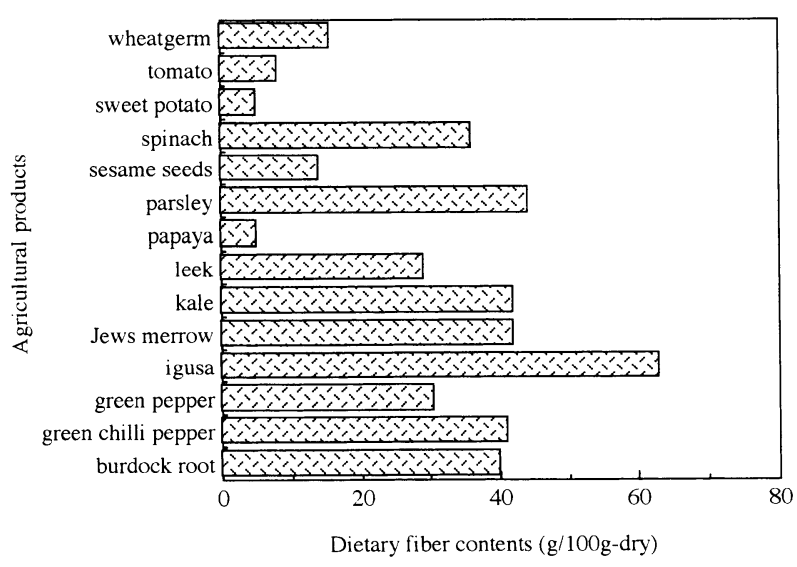

Fig. 1 Dietary fiber contents of various agricultural products.

トマト，サッマイモ，パパイヤは $5 \sim 15 \%$ 程度の食物 繊維含有率であった。これらの結果と比べるとイグサの 食物繊維含量は，農作物の中でもかなり高い部類に属す るものと考えられる。食物繊維は肥満防止作用，コレス テロール上昇抑制作用，血糖值上昇抑制作用，大腸ガ ンの発生抑制作用，有害物質の除去作用など多くの効 能を有していることがすでに明らかになっている [7].

\section{4. イグサの抗菌作用}

イグサは独特の香りを有する作物である。このような 独特の香りを有する作物には抗菌性を有するものが多く， 古くから香辛料，シソの葉，ワサビなどは腐敗防止の食 材として食生活に取り入れられて打り，一部は日持向上 剂として市販されている $[8 ， 9]$ ，そこでイグサ水抽出液 について抗菌性を調べた結果, グラム陰性細菌，グラム 陽性細菌のいずれに対しても抗菌性を有していた $[10]$. 
イグサ水抽出液の抗菌スペクトルをTable 2 に示す. イグサ水抽出液を様々な濃度に希勫して，ディスクから 得られる阻止円の有無によって, 最小発育阻止濃度 （MIC）を求めた。つまり MIC 值が小さいほど, 検定菌 に対して強い抗菌性を有しているということになる。そ の結果, Salmonella 属菌, Staphylococcus 属菌, EHEC O157，O26，O111をはじめとする食中毒細菌 やBacillus 属菌, Micrococcus 属菌などの腐敗細菌に対 して, MIC 值で $0.78 \sim 100 \mu \mathrm{g} / \mathrm{ml}$ の範囲で抗菌活性が 認められた。もっとも強い抗菌活性を示したのは非病原 性大腸菌である Escherichia coliであり， MIC 值は 0.78 $\mu \mathrm{g} / \mathrm{ml}$ であった。 また, 腐敗細菌であるPseudomonas 属 菌や酵母, 系状菌類には抗菌性は認められなかった。

さらに，腸内における有用な細菌類 (Bifidobacterium bifidium, Enterococcus faecalis, Enterococcus faecium. Streptococcus bovis）を検定菌として，イグサ水抽出液 の抗菌性について調べた（Table 2)。その結果，いず れの腸内細菌類においても抗菌性は認められなかった。 イグサが食中毒細菌や腐敗細菌に特異的に作用して，腸 内に生息する善玉菌に対して抗菌性を示さない結果は, 緑茶由来のポリフェノールの抗菌スペクトルと非常に類 似している[11]。抗菌成分の特定はこれからの課題であ るが，イグサは食中毒未然防止を目的とした抗菌剤とし ても利用可能ではないかと期待される.

リュウゼッラン科であるユッカはイグサと同様に Staphylococcus aureus, Bacillus subtilisに対して抗

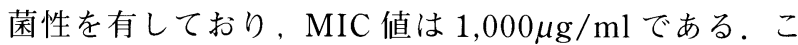
の值に比べると，イグサの抗菌作用は高いといえるが， ユッカはイグサで抗菌性を示さなかった酵母，力ビ類に 対して抗菌活性が検出されている[12].

また，化学性の保存料として広く使われている安息香酸 の Staphylococcus aureus, Bacillus subtilis, Escherichia coli に対する MIC 值はそれぞれ 1,000，500，2,000
Table 2 Minimum inhibitory concentration (MIC) of Juncus effusus var. decipiens extract.

\begin{tabular}{lc}
\hline \multicolumn{1}{c}{ Test organism } & MIC $(\mu \mathrm{g} / \mathrm{ml})$ \\
\hline Bacillus subtilis IFO 3335 & 1.6 \\
Salmonella typhimurium IFO 13245 & 3.1 \\
Micrococcus luteus IFO 3333 & 1.6 \\
Escherichia coli IFO 3972 & 0.78 \\
Staphylococcus aureus IFO 12732 & 50 \\
Pseudomonas fluorescens IFO 3507 & - \\
& \\
Saccharomyces cerevisiae IFO 2363 & - \\
Aspergillus oryzae IFO 30102 & - \\
Rhizopus japonicus IFO 4697 & - \\
& \\
EHEC O157:H7 (VT1) & 100 \\
EHEC O157:H7 (VT2) & 100 \\
EHEC O157:H7 (VT1, VT2) & 100 \\
EHEC O26:H11 (VT1) & 100 \\
EHEC O111:H8 (VT1) & 100 \\
Bifidobacterium bifidium IFO 14252 & - \\
Enterococcus faecalis IFO 3971 & - \\
Enterococcus faecalis IFO 12580 & - \\
Enterococcus faecium IFO 3128 & - \\
Streptococcus bovis IFO 12057 & - \\
Bacteroides vulgatus IFO 14291 & - \\
\hline
\end{tabular}

$(-;$ not detected $)$

$\mu \mathrm{g} / \mathrm{ml}$ である.イグサの抗菌活性はこれらの結果を上 回るものであるが, 安息香酸においても酵母, カビ類に 対して抗菌活性が検出されている $[13]$.

これらの報告より，イグサは細菌増殖抑制を目的とし て抗菌剂や防腐郕として使用することにはふさわしい が，酵母やカビ類増殖抑制を目的とした実用化にはふさ わしくないものと結論づけることができる.

また，イグサが天然の抗菌素材として，どの程度，熱 や $\mathrm{pH}$ に強いのかということについて調べた $[10]$ 。熱

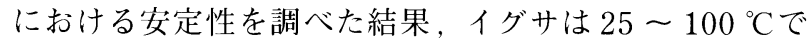
60 分間保持を行っても抗菌性の低下は認められなかっ
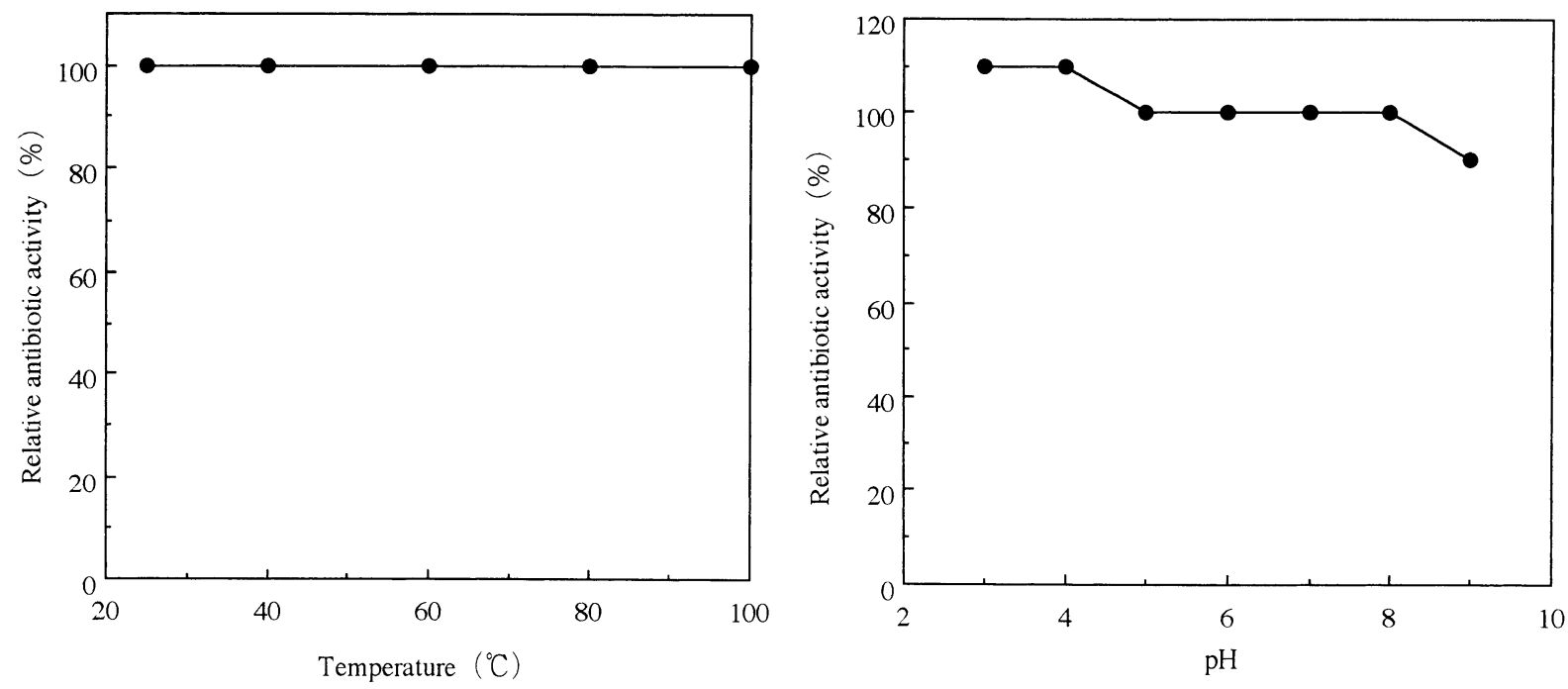

Fig. 2 Effect of temperature and PH on stability of Juncus effusus var. decipiens extract. 
た (Fig. 2)。この結果より, 食品の加工温度に対してもイ グサの抗菌性は安定的に保持されることが明らかとなった。

さらに, $\mathrm{pH}$ 安定性についても調べた結果，イグサは 酸性域でとくに安定であり，塩基性領域（pH9.0）では やや不安定であるものの相対残存抗菌活性は $90 \%$ であっ た (Fig. 2).

\section{5. イグサの日持向上剤としての応用}

イグサは幅広い細菌に対して抗菌作用を有していたこ とから，イグサを食品の日持向上剤として利用すること を目的として, スポンジケーキの腐敗試験と豆腐保存液 の腐敗試験を行った $[10]$.

イグサを添加したスポンジケーキはイグサを添加しな かった場合に比べて, $30{ }^{\circ} \mathrm{C}, 3$ 日間の保存に対して, 明 らかに一般細菌数が少ない傾向にあった（Fig．3）。さ らにイグサ添加濃度が高くなればなるほど，保存したス ポンジケーキの一般細菌数は少なくなる傾向にあった。 $30{ }^{\circ} \mathrm{C}, 3$ 日間という劣悪な環境下での保存で，イグサ 無添加ケーキとイグサを $40 \mathrm{~g} / 100 \mathrm{~g}$-cake の濃度で添加 したケーキの一般細菌数は約 2 オーダーの差であった。 さらに特筆すべきことは，イグサを添加した場合，スポ ンジケーキ作成後（0日目）の一般細菌数が検出されな かったことである. $10 \mathrm{~g} ， 20 \mathrm{~g}, 30 \mathrm{~g} / 100 \mathrm{~g}$-cake のイ グサ添加スポンジケーキでは， $30{ }^{\circ} \mathrm{C} ， 1$ 日保存において 一般細菌が検出されたが，40 g/100g-cakeのイグサ添 加スポンジケーキでは一般細菌が検出されなかった。し かし，2 日保存以降では $40 \mathrm{~g} / 100 \mathrm{~g}$-cake のイグサ添加 スポンジケーキに扔いても，一般細菌が検出された。

豆腐は食品の中でも水分含量が多いことから, 腐りや

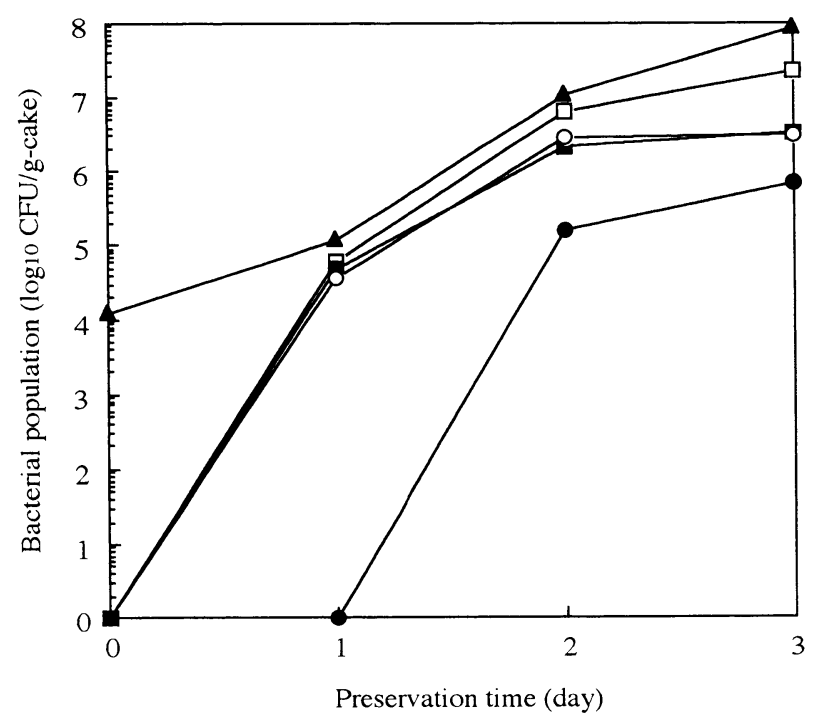

Fig. 3 Changes of the bacterial population on a cake at $30^{\circ} \mathrm{C}$. Juncus effusus var. decipiens was contained in the cake respectively $0 \mathrm{~g}(\mathbf{\Delta}), 10 \mathrm{~g}(\square), 20 \mathrm{~g}(\mathbf{\square}) .30 \mathrm{~g}(\bigcirc)$, and $40 \mathrm{~g}$ () $/ 100$ g-cake.

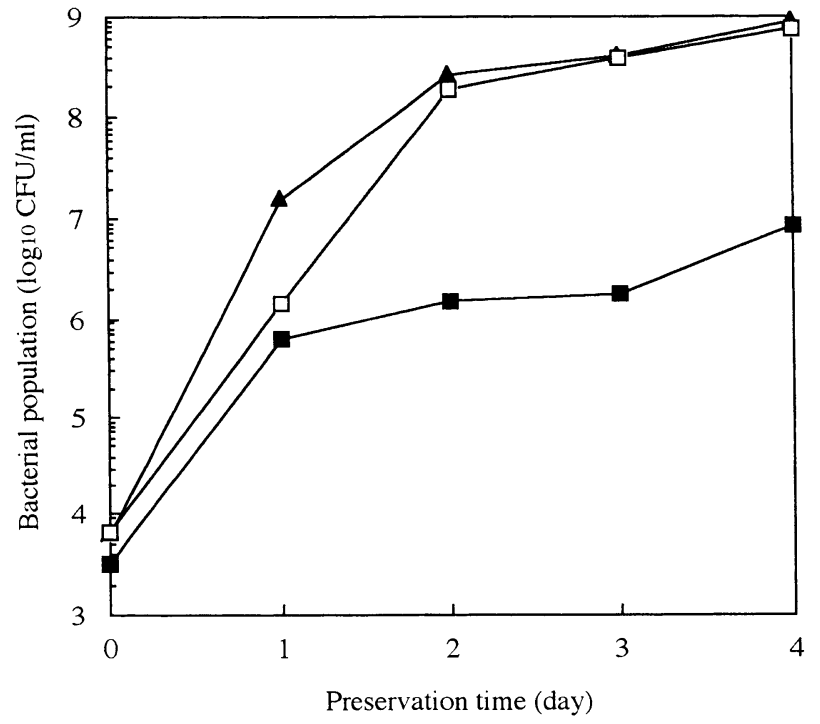

Fig. 4 Changes of the bacterial population in a tofu preservative at $30^{\circ} \mathrm{C}$. Juncus effusus var. decipiens was contained in the preservative respectively $0 \mathrm{~g}(\mathbf{\Delta}), 0.05 \mathrm{~g}(\square)$, and $0.1 \mathrm{~g}$ (ם) $\mathrm{ml}$.

すい食品の一つに挙げられる，このような背景から，豆 腐の保存液にイグサを添加することで，豆腐の日持が向 上するかどうかを試みた（Fig. 4)。その結果，イグサ 濃度 $0.05 \mathrm{~g} / \mathrm{ml}$ の保存液では $15{ }^{\circ} \mathrm{C}, 1$ 日保存で, 滅菌 水での保存に比べて, 1 オーダーの一般細菌数差が認め られた。しかし 2 日保存以降は, 滅菌水保存とほとんど 差が認められなくなった。これに対してイグサ濃度 0.1 $\mathrm{g} / \mathrm{ml}$ の場合では，1 日保存で, 滅菌水での保存に比べ て、1オーダーの差が認められた。しかし，それ以降の 保存ではイグサ抽出液を保存液とした場合, 一般細菌数 の増殖度は比較的低く, $15{ }^{\circ} \mathrm{C}, 4$ 日間の保存では滅菌 水での保存に比べて，2オーダーの差にまで拡がった。

以上の結果より，イグサを使用することでスポンジケー キや豆腐の日持を向上できることが明らかとなった．日 持向上骫を目的として使用されているものにモウソウチ ク抽出物, イチジク葉抽出物, 生ダイズ抽出物, シソ抽 出物，ブドウ果皮抽出物，ニンニク抽出物など多くの天 然物があげられる。モウソウチク抽出物は $100 〜 400$ $\mu \mathrm{g} / \mathrm{ml}$ の濃度で細菌類を阻止することから, カット野 菜、生肉、うどん, かまぼこ等の食品に日持向上俨とし て使用されている[14]。今後, イグサ抽出物においても 細菌類増殖抑制を目的とした日持向上剤として, 様々 な食品に使用されていくことを期待してやまない．

\section{6. スーパーオキサイド消去活性}

近年, 活性酸素の研究が進むにつれて, 生体内におけ る活性酸素の毒性が明らかになってきた。スーパーオキ サイドは活性酸素種の中の一つであり, 少量では免疫効 果を発揮するものの, 体内に多量に蓄積した場合, ガン 


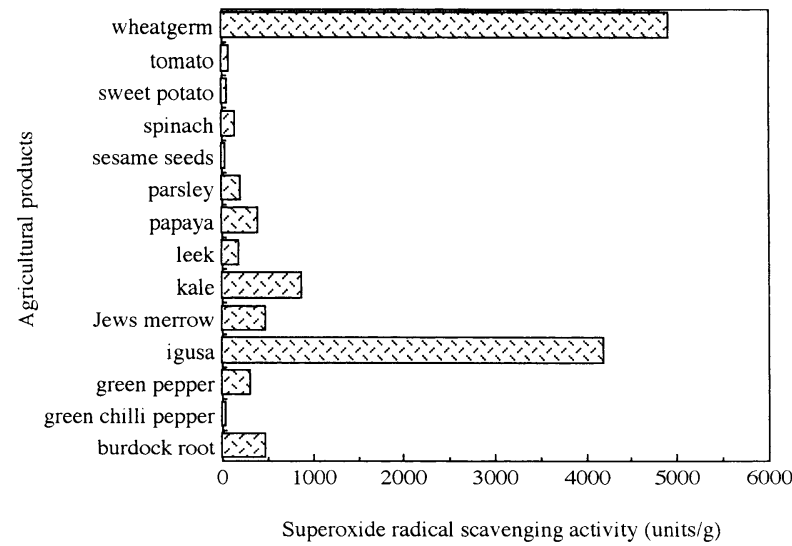

Fig. 5 Superoxide radical scavenging activity of various agricultural productss.

や動脈硬化, 糖尿病, 老化, アトピ一性皮膚炎, アレル ギー疾患など様々な病気を引き起こすことで知られてい る。活性酸素は酒やタバコを飲んだり，ストレスが溜まっ たり，空気が污れた環境で生活したり，食品添加物を多 く含む食品を食べることで, 体内に蓄積される。しかし， これらは現代生活において避けては通れないものばかり であり，活性酸素を消去する食品を日常的に食べること が必要であると考えられている。

そこで電子スピン共鳴（ESR）法を用いて，イグサの スーパーオキサイド消去活性（SOD 様活性）を測定し た。その結果，イグサ（生）は4200 単位/gのSOD 様 活性を有していた。また，青汁の原材料として知られて いるケール（生）のSOD 様活性を測定した結果，880 単位 $/ \mathrm{g}$ であった。

氏家は様々な農作物の SOD 様活性を調べている [15]。これによると小麦肧芽（生）が 4900 単位/g，ゴ ボウ（生），モロへイヤ（生），パパイヤ（生）が 400 500 単位/g, ピーマン（生）, パセリ（生），二ラ (生)，ホウレンソウ（生）が 150 〜 300 単位/g, トマ ト（生）, サツマイモ(生), シシトウ(生), ゴマ(乾 燥）が 30 〜 100 単位 $/ \mathrm{g}$ であった. イグサとケールの結 果と氏家の結果をまとめたものが Fig. 5 である.これ によるとイグサや小麦肧芽の SOD 様活性は様々な農作 物の中でも高いと言える。

\section{7.おわりに}

筆者らが明らかにしてきたイグサの抗菌作用，活性酸 素の消去能，食物繊維が豊富であることに着目して，イ グサの最大産地である熊本県では，ここ 1 年でイグサの 食品産業への利用が急激に進みつつある。熊本市内の製 薬会社は，イグサが青汁の原材料であるケールに比べて， 食物繊維, SOD 様活性, ビタミン A 含有量などの点で 優れた機能性を有している点に着目して，イグサ青汁の 商品化に成功した。また，八代市の環境市民団体「市
イチャーやつしろ」は，イグサの抗菌作用に着目して， イグサで廃油石検を作り商品化した。また，熊本県内の 豆腐業者は，豆腐にイグサを添加することで日持を向上 させたイグサ豆腐を開発している。ささらに，八代市内の 中華料理店では，餃子の皮にイグサを混ぜた「イグサ餃 子」や，麺の中にイグサを混ぜて「イグサ中華麺」とし てメニューに出している．イグサを健康野菜として活用 する動きも今後さらに広がってゆくものと期待している.

日本政府は昨年, イグサに対して初の暫定的なセーフ ガードを発動したが，その後正式発動されることなく今 日にいたっている。今後，イグサの様々な効能をさらに 見い出すことにより，健康食品から医薬品にまで利用範 囲を広げ，胃以外の新しい産業を創出することにより， 低迷している日本のイグサ産業の需要拡大を進めていく べきであると考えている。

謝辞

本研究を遂行するにあたり，株式会社丸美屋上村 和也氏，松本紳二氏，八代市産業振興部農政課 山本 昭三氏，坦下昭博氏，田中和彦氏，JA やつしろ，国立 八代工業高等専門学校生物工学科 大森智子氏, 杉本 加菜子氏，吉村裕子氏，ワンドリーム 高林幸則氏，牛島 健介氏, 藤岡正一氏, 熊本県保健環境研究所微生物科 学部 甲木和子氏, 宮坂次郎氏に感謝の意を表します.

\section{引 用 文 献}

1）熊本県農政部；“熊本の農業 1999”熊本県, 1999, p. 19.

2）八代市産業振興部農政課；“八代市のいぐさ”，八代市, 2000 , p. 14.

3）佐竹元吉, 伊田喜光, 根本幸夫 ; “漢方 210 処方生薬解 説”, じほう, 2001, p. 165.

4）赤松金芳; “新訂和漢薬”, 医茵薬出版株式会社, 1980 , p. 595.

5）神戸中医学研究会 ; “漢薬の臨床応用”, 医柬薬出版株式 会社, 1979, p. 149-150.

6) 佐藤 信 ; “統計的官能検査法”, 日科技連出版社, 1985, p. 37-55.

7）栄養機能化学研究会; “栄養機能化学”, 朝倉書店, 1996, p. 131-137.

8) 酒井重男; 食の科学, 283, 24-35 (2001).

9) 関山泰司；化学と工業，52 (1)，31-34 (1999).

10）森田 洋, 塩澤正三, 大森智子, 志水由紀, 稲田剛夫; 日 本防菌防徽学会誌, 30 (12), 印刷中 (2002).

11）川上正子, 原 征彦; New Food Industry, 40 (1), 3340 (1997).

12）田村幸吉；クリーンテクノロジー， 3，67-71 (1996). 
13)霜 三雄，福住栄一; “食品防腐郕の使い方”，信貴書院、性が認められた。抗菌成分は熱や酸に強く，25〜 1965, p. 109.

$100{ }^{\circ} \mathrm{C}$ で 60 分間，または $\mathrm{pH} 3 \sim 9$ において安定であっ

14) 仁科淳良 ; New Food Industry, 30 (10), 17 (1988).

た。また， $30{ }^{\circ} \mathrm{C} ， 3$ 日間保存したイグサ無添加ケーキの

15) 氏家 隆；食品と開発，31 (2)，46-47 (1996).

要 旨

イグサはそのままでは灰汁が強く食用にあまり適さな いが，3 分間水煮処理をすることにより，嗜好性を高め ることができた。イグサの食物繊維含量は他の農作物に 比べて，非常に高い值であり，無水物換算で $100 \mathrm{~g}$ あた り $63 \mathrm{~g}$ もの量を占めている。イグサは食中毒細菌や腐 敗細菌に対して，MIC 值で $0.78 \sim 100 \mu \mathrm{g} / \mathrm{ml}$ の抗菌
一般細菌数はイグサを $40 \mathrm{~g} / 100 \mathrm{~g}$-cake の濃度で添加し たケーキに比べて, 約 2 オーダー多かった。 $15{ }^{\circ} \mathrm{C}, 4$ 日 間保存したイグサ無添加豆腐保存液の一般細菌数は, イグサを $0.1 \mathrm{~g} / \mathrm{ml}$ の濃度で添加した保存液に比べて, 約 2 オーダー多かった。イグサは 4200 単位/gのスーパー オキサイド消去活性（SOD 様活性）を有していた。今 後イグサの用途を健康食品から医薬品にまで広げ，畳以 外の新しい産業を創出することにより，低迷している日 本のイグサ産業の需要拡大を進めていくべきであると考 えている。 